\title{
ARSENAL REPOSITION AND OPTIMIZATION IN SUPPORTING NAVAL OPERATIONS TO IMPROVE NATIONAL RESILIENCE
}

\author{
Winarno Umar*, Fadli Mohammad, Moeljadi, Prianti Desi Dwi \\ University of Brawijaya, Malang, Indonesia \\ *E-mail: umarsubarja@gmail.com
}

\begin{abstract}
The current strategic environmental conditions affect the state's security conditions, especially interference from abroad. Anticipating these possible threats, military forces must be strong with reliable alusista. In order to support the distribution of defense equipment, especially weapons and ammunition (weapons and ammunition), the arsenal has a very large role, these activities must be well organized. In the implementation of support for weapons and ammunition needs to operating units within the Indonesian Navy, there are still several obstacles, including frequent delays in distribution. This is due to the centralized location of the arsenal and the inadequate warehousing system. For this reason, the arsenal must be able to distribute weapons and ammunition needs effectively and efficiently. The purpose of this study was to determine and analyze the implementation of arsenal dispersion into three places, its implications for the Indonesian Navy's operations and how to optimize the distribution of weapons and ammunition, using a normative juridical approach through strategic, economic and security assessments of the Indonesian Navy's operations. The conclusion is that the dispersion of the arsenal into three places and the optimization of the warehouse turned out to be closely related in terms of the distribution of weapons and ammunition.
\end{abstract}

\section{KEY WORDS}

Arsenal, distribution, weapons, ammunition.

The Indonesian sea area which is the border between countries is an area that is very vulnerable to the threat of various negative actions carried out by transnational actors. It takes a strong resilience in the sea to be able to ward off various threats. By having good sea resilience, it is believed that it will be able to maintain the national defense area in the Indonesian Seas. Sea power is the most important element for the progress and glory of a country, which if the sea power is empowered, it will improve the welfare and security of a country. On the other hand, if the sea power is ignored, it will result in losses for a country or even bring down the country (A.T. Mahan, 2012).

One of the new forms of security threats in Southeast Asia today is the South China Sea (SCS) conflict. This conflict involved six countries as direct claimants, namely China, Taiwan, Vietnam, the Philippines, Brunei Darussalam, and Malaysia. This is due to the strategic location of the SCS and the potential contained therein and Indonesia is indirectly involved in it. Indonesia is very careful in dealing with disputes in the South China Sea (Tndungan, 2020). In the SCS conflict, in addition to the tensions that arise due to overlapping claims between the disputing countries that have not been stopped until now, there are also unfavorable developments, especially regarding the relationship between the two ASEAN member countries, namely Vietnam and the Philippines and China. The Philippines has given various reports of violations by Chinese vessels passing through the disputed waters, and there have even been incidents between Chinese patrol boats and Filipino fishing vessels. China claims the disputed territory based on the Chinese ownership of the sea area and two groups of Paracel and Spratly islands since 2000 years ago, then the Chinese government claims to have issued a map detailing China's sovereignty over the South China Sea or South China Sea in 1947, known as the South China Sea. "Nine Dashed Line" (Muhar Junef, 2018). 
Besides these conflicts, there are still many other conflicts to be observed as studies in the security sector that will add insight, which needs attention to how these problems can be resolved without prolonged conflict. Currently, global power can cause a country's internal problems to become problems that involve many countries (Dunn and Mauer, 2010). Considering that steps to resolve this conflict will take a long time because of the complexity of the problems and the condition of the Indonesian National Armed Forces (TNI) Main Weapon System (Alutsista), especially the Indonesian Navy (TNI AL) which is still not strong/minimum or Minimum Essential Force (MEF), then other efforts are needed to support the Indonesian Navy to keep the territory of Indonesia and the region safe until the problem of this territorial claim is resolved. The current condition of the defense equipment system is very forced to still use the old defense equipment system, because it still prioritizes welfare development and has not yet modernized the defense equipment system but is currently very urgent and must be modernized more quickly (Rosidine, 2021).

Basically the TNI was formed to carry out state duties in the field of defense in the face of various threats and disturbances to the integrity of the nation and state. In addition to carrying out these defense tasks, the TNI is also prepared to carry out tasks in the context of supporting the national interest in accordance with statutory regulations. The main tasks of the Indonesian Navy are: 1) carrying out the tasks of the Marine Corps in the defense sector; 2) enforce the law and maintain security in the marine area of national jurisdiction in accordance with the provisions of national law and ratified international law; 3) carry out the tasks of naval diplomacy in the context of supporting foreign policy policies set by the government; 4) carry out the duties of the TNI in the development and development of the strength of the marine dimension; and 5) implementing the empowerment of marine defense areas (Kep. Pang TNI, 2018).

To support the operations carried out by the Indonesian Navy throughout the year by the Warship, Marines, Special Forces and other units, the distribution of weapons and ammunition greatly affects the success of the operations carried out. The operations carried out by the TNI consist of War Military Operations (OMP) and Military Operations Other Than War (OMSP) (Kep. Pang TNI, 2018). For example, the implementation of the OMP to deal with aggression and armed conflict with one or more countries is carried out with a universal state defense system through the stages of deterrence, prosecution and recovery. The OMP and OMSP must be supported by the need for adequate weapons and ammunition to support the smooth and successful operations carried out.

Arsenal is a place to store, maintain, repair, distribute and destroy weapons and ammunition which is categorized as a very strategic and vital place. As one of the most vital objects, the arsenal must receive special treatment regarding its safety and control. Arsenal is in a very strategic position because it stores and maintains weapons and ammunition that will be used to support the success of the Indonesian Navy's operational tasks. Currently the Indonesian Navy's Arsenal is concentrated in one place, this of course greatly affects the strategy that decision makers will choose and the security of the arsenal from possible enemy sabotage. Considering that the TNI AL's defense equipment is spread throughout Indonesia, it is necessary to store weapons and ammunition elsewhere as a back up in case of sabotage in the current arsenal.

Arsenal is in charge of supporting supplies and weapons and ammunition for weapons and ammunition to all Indonesian Navy units. Alutsista that uses weapons and ammunition in the Indonesian Navy include: Warship's under the control of Fleet Command (Koarmada) 1, 2 and 3, Warship's under the control of the Military Sea Cross Command (Kolinlamil) namely the Military Sea Crossing Unit (Satlinlamil) 1 and 2, Warship's under control of the Hydrographic and Oceanographic Center of the Indonesian Navy (Pushidrosal) and the Marines, namely the Marine Troops (Pasmar) 1, 2 and 3. Operations carried out by these units will be constrained by the slow distribution of weapons and ammunition due to long distances and security disturbances from the enemy to obtain weapons and ammunition needed. Therefore, dispersing or making the arsenal into three different places will greatly assist the distribution of weapons and ammunition to units in need. 
Strategic location is the area where a company's production operations are placed that can provide maximum benefits to the company because the purpose of location strategy is to maximize location benefits for the company. Location greatly affects costs, both fixed costs and variable costs. Location greatly affects the risks and profits of the company as a whole (Rusdiana, 2014). Along with the statement, the location of the arsenal is one of the factors that support the distribution of weapons and ammunition to be carried out effectively and efficiently, the location of the arsenal being centralized in one place is an obstacle for the distribution of weapons and ammunition. The obstacle is that the distance of distribution or delivery of weapons and ammunition far from the user will have implications for time so that it affects the results of the operations carried out. From the point of view of strategy or war tactics, the arsenal in one place will be very different from the arsenal in three places in terms of making strategic decisions or what war tactics will be carried out. Likewise, from an economic and security perspective, it will also be very influential if the users of weapons and ammunition are far from the arsenal compared to if the users of the weapons and ammunition are close to the arsenal. Arsenal in the three places will automatically have a deterrent effect on future opponents of Indonesia and they will think again about confronting Indonesia. In essence, it will be more effective and efficient if the arsenal is in three strategic places and close to the users of weapons and ammunition. So that it will increase the strength of the Navy and national security.

An arsenal warehouse that is managed efficiently and systematically has a huge impact on the speed of distribution and security of goods. With the high activity in and out of goods, the level of difficulty in managing the warehouse is usually high as well. There are several ways that can be applied so that warehousing activities in the arsenal avoid chaos and errors, so that in the end make warehouse performance increase and be more effective and efficient, this is by improving the Warehousing Management System, Warehouse Computerization, Infrastructure Improvement and Transportation Facilities. .

Based on the description above, the author conducted a study to determine the factors that can support the successful distribution of weapons and ammunition to user units by changing the distribution of weapons and ammunition in one centralized place into a distribution of three arsenals which will be more effective and efficient. To discuss the main problems in this paper, the author's personal experience approach during 4 years of service in the arsenal, literature on TNI operations, operations management, warehousing and others related to distribution is used.

The research method used in this paper is a qualitative approach with descriptive data analysis which aims to describe and analyze matters related to distribution so that the research results from the data that have been obtained can provide strong support for the theory or concept used in this paper. Qualitative research is research that intends to understand phenomena about what is experienced by research subjects such as behavior, perceptions, motivations, actions, etc., holistically, and by means of descriptions in the form of words and language, in a special natural context and by utilizing various natural methods (Moleong, 2016). Descriptive method is a method used to analyze data by describing or describing the data that has been collected as it is without intending to make conclusions that apply to the public or generalizations (Sugiyono, 2013).

\section{RESULTS AND DISCUSSION}

There are at least two things that make the South China Sea (LCS) a water area that is prone to major conflicts today and in the future. First, the South China Sea is a water area with rich natural resource potential, especially oil and other energy sources, with several clusters of islands scattered around it, which are competing for mutual claims by several countries around the region, such as China, Vietnam. , Philippines, Taiwan, Malaysia, and Brunei Darussalam. Second, because of its location in the international shipping lanes that pass through the Malacca Strait, one of the busiest in the world, and is a trade link from Europe to Asia and America to Asia and vice versa, through the territorial waters of countries in at least 3 countries. important regions, namely Southeast Asia, East Asia and Asia-Pacific, 
so in addition to the claimant countries, countries located around the LCS such as Indonesia and Singapore, and even the US, have an interest at all times in maintaining stability and security in the LCS.

Anticipating the development of increasingly heated conflicts in the South China Sea and the threat to state sovereignty, the TNI as a means of state defense has a function as a deterrent to every form of military threat and armed threat both coming from outside and from within the country that threatens state sovereignty, territorial integrity, and safety. nation. Strategy, logistics and tactics are an inseparable unit in carrying out an operation. Integrated logistical support in a base is very influential on the results of operations that have been carried out. Integrated logistical support can be grouped into 5 (five) namely maintenance support, weapons and ammunition support, personnel support, training education and base facility support.

In the military, strategy and logistics are closely linked together. Thus an order must see strategy in relation to logistics and must see logistics in relation to strategy. Where strategy determines the broad objectives and methods for achieving them, tactics determine the placement of specific troops to achieve strategic objectives, logistics provides the means to create and support combat troops (Henry E. Eccles, 1959). Thus, strategy and tactics provide a pattern for organizing military operations, while logistics provides the means. Strategy and tactics are ways used by leaders to achieve the goals of a military activity, namely winning the war. For this purpose, apart from strategy and tactics, one thing that is dominant and greatly supports the achievement of victory is adequate logistical support for personnel and equipment used. These three elements are inseparable because they influence each other.

TNI readiness must continue to be improved to face various potential disturbances and threats from other countries that threaten state sovereignty. The distribution of weapons and ammunition is one of the keys to success in carrying out support for operations carried out by the Indonesian Navy. The distribution of weapons and ammunition within the Indonesian Navy will be successful if it is supported by adequate hardware and software. In this case the arsenal has a big role in carrying out the distribution of weapons and ammunition. For the successful distribution of weapons and ammunition to support the Indonesian Navy's operations, the Navy needs to develop a more massive arsenal by dispersing the arsenal into three places and optimizing the warehouse to be more modern.

The TNI as a State Defense institution based on Law number 34 of 2004 concerning the Indonesian National Army in Article 7 has the main task of upholding state sovereignty, maintaining the territorial integrity of the Unitary State of the Republic of Indonesia based on Pancasila and the 1945 Constitution of the Republic of Indonesia, as well as protecting the entire nation and the entire homeland of Indonesia from threats and disturbances to the integrity of the nation and state. The main tasks as referred to in paragraph (1) are carried out by: (a) OMP; (b) OMSP (UU RI NO 34 TH 2004 concerning TNI), 2004).

Although Law Number 34 is the legal basis and impetus for the TNI to take various steps for change, if you pay attention to various recent polemics, you will find various irregularities and difficulties in implementing what is stated in Law Number 34, one of which is contained in Article 7 Paragraph 2 regarding the separation of the TNI's main duties through OMP and OMSP and the implementation of OMSP which must be based on state political policies and decisions in accordance with Paragraph 3. Referring to the separation and explanation of what is meant by OMP, namely all forms of mobilization and use of TNI forces to fight military of another country that acts of aggression against Indonesia or in an armed conflict with one or more other countries which is preceded by a declaration of war and subject to international law of war, so far no TNI operations or activities can be categorized as OMP.

The purpose of determining the location is to minimize material handling costs, increase room utilization efficiency, increase labor utilization efficiency, reduce process constraints, and facilitate communication and interaction between workers and their supervisors or between workers and company customers (Taylor and Russell, 2011). Determination of the location is one of the strategic operational decisions that also determine 
the efficiency of operations that will be carried out in the long term. Determination of a good location will contribute to increasing service productivity. This is due to the smoothness that will be managed in the form of weapons and ammunition and other factors that support the warehousing process, starting from the preparation process, storage until the process of handing over weapons and ammunition to users.

The implementation of Arsenal's duties to support weapons and ammunition to units within the Indonesian Navy is faced with the large area that must be served, the arsenal location must be easily accessible by the unit so that the distribution of weapons and ammunition can be carried out effectively and efficiently So the determination of the location of the new arsenal that can reach units using weapons and ammunition effectively and efficiently is in three different places that are strategic, economical, safe and fast and have a deterrent effect. Based on the calculation of military strategy calculations, distribution costs, security and speed of distribution, the locations for the three arsenals are: Arsenal I in Tanjung Pinang, Arsenal II in Madura and Arsenal III in Sorong.

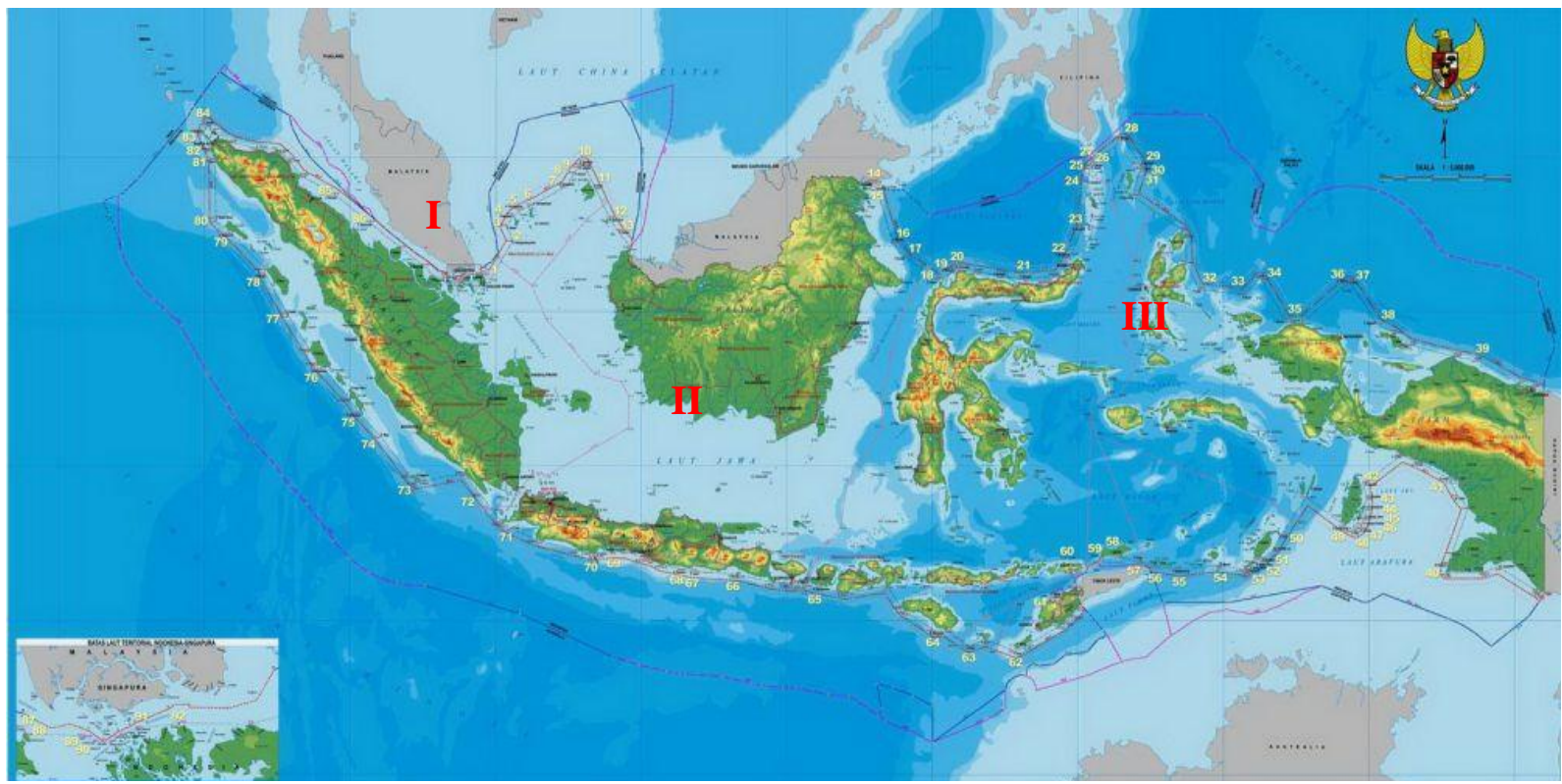

Figure 1 - Arsenal I, II and III positions

Making a big city the place to choose a business location today may no longer be an absolute requirement. The basis for establishing a business must consider costs and benefits, namely the business must be established. If the big city is not suitable for the type of business and the profit target, then placing the business location in a big city is not a solution (Rusdiana, 2014). Arsenal's location into three Arsenals is based on the area to be served according to the distance between Arsenal and the users to be served. The location of Arsenal was built adjacent to the Indonesian Navy's Main Base (Lantamal), this is intended so that the security of the arsenal can be carried out by the Indonesian Navy Base (Lanal) under Lantamal which is adjacent to the arsenal. The division of duties and responsibilities for the distribution of weapons and ammunition from the three arsenals are:

- Arsenal I, located in Tanjung Pinang, Tanjung Pinang, is a city with adequate infrastructure with a representative port and dock for loading and unloading weapons and ammunition. Arsenal I will serve Indonesian Navy units operating around or closer to Tanjung Pinang and other Indonesian Navy units located in western Indonesia, namely: Koarmada I in Jakarta, Lantamal I in Medan, Lantamal II in Padang, Lantamal III in Jakarta, Lantamal IV in Tanjung Pinang, Lantamal XII in Pontianak, Marines I and KRI are carrying out operations in western Indonesia;

- Arsenal II is located in Batuporon Madura, Arsenal II is the current arsenal with adequate infrastructure with representative ports and docks for loading and unloading 
weapons and ammunition. Arsenal II will serve Indonesian Navy units operating around or closer to Surabaya and other Navy units located in the central region of Indonesia, namely: Koarmada II in Surabaya, Lantamal V in Surabaya, Lantamal VI in Makassar, Lantamal VII in Kupang, Lantamal VIII in Manado, Lantamal XIII in Tarakan, Marines II and KRI who are carrying out operations in the central part of Indonesia;

- Arsenal III, located in Sorong, Sorong is a city with adequate infrastructure with a representative port and dock for loading and unloading weapons and ammunition. will serve Indonesian Navy units operating around or closer to Sorong and other Navy units in eastern Indonesia, namely: Koarmada III in Sorong, Lantamal IX in Ambon, Lantamal X in Jayapura, Lantamal XI in Merauke, Lantamal X in Jayapura, Lantamal XI in Merauke, Lantamal XIV in Sorong, Marines III and KRI who are carrying out operations in eastern Indonesia.

In general, the relationship between strategy and logistics follows a broad pattern. First and foremost, the fundamental relationship between scope and strategic plans is both governed by logistical capabilities. Closely related to this is the composition, balance and distribution of forces determined by the complex interrelationships between strategic, logistical and tactical considerations. The question of site selection for a naval base is a mix of logistical strategic considerations (Henry E. Eccles, 1959). The arsenal location is determined to be three places, of course, based on calculations in terms of strategic, logistical and tactical benefits where users will be more effective in carrying out loading / loading weapons and ammunition.

Strategic and economic. The location decisions of manufacturing and service organizations determine the company's success. Mistakes made regarding location can affect efficiency. Location greatly affects the risks and profits of the company as a whole (Rony and Nur Asni, 2019). From this statement, it is closely related to the determination of a strategic location that will determine the success of an operation carried out in the business and military fields. Faced as a vast archipelagic country, the division of the arsenal into three places is an advantage for decision makers or war commanders in making decisions, they will be able to determine what strategy will be taken to deal with the ongoing operation. This is because the users of weapons and ammunition do not require a large effort to load/unload weapons and ammunition compared to just one arsenal place. For example, if the operation is carried out in Aceh, it will be more strategic and more efficient if the reloading of weapons and ammunition is carried out in Tanjung Pinang compared to the reloading of weapons and ammunition in Madura.

Safe and fast. Security and speed are the keys to the success of a weapons and ammunition distribution process. This not only provides benefits to the user, but also to the arsenal as a benchmark for successful distribution of weapons and ammunition. The availability of weapons and ammunition needed by users must be supported according to needs quickly and safely. The separation of the arsenal into three places makes the security of the availability of weapons and ammunition more secure because the opposing party who wants to destroy the arsenal will require a very heavy effort to destroy the arsenal in three locations with great distances and in the event of war the availability of weapons and ammunition will be safer compared to one. centralized place. For example, if one of the arsenals is attacked by the enemy, there are at least two arsenals that can still be relied on to provide weapons and ammunition to war actors. Availability of weapons and ammunition during the war will determine victory in the war, with three different places will ensure the availability of weapons and ammunition safely. The speed at which weapons and ammunition arrive to the user is also very important because it will be fatal if the weapons and ammunition arrive late to the user. With the location of the arsenal in three places, weapons and ammunition users will be able to refill weapons and ammunition more quickly to the nearest arsenal.

Every country seeks to have military assets capable of providing a deterrent effect. The intent and purpose is so that no other country will think of attacking that country, so that war can be easily avoided. In addition, the effect of trepidation is also usually used by many 
countries to strengthen any diplomatic efforts that are being and will be carried out (Patku Yayan, 2021). Although the asset price that must be held is not something cheap, it is still far below the budget amount that must be spent if a country has to go to war. Likewise, building the arsenal into three places will require a very large cost, however, with the three existing arsenals it will definitely increase the fear and make other countries who wish to attack Indonesia have to think twice because the TNI has weapons and ammunition. adequate.

If we are planning to build a new warehouse, then we must examine the dynamic situation, usually we tend to think that the situation is static, when in fact it is always moving and changing. Therefore, even though we have planned it often to a very detailed level, we must provide enough opportunities for adjustments. Construction of a warehouse always takes a lot of time, effort, thought and cost. After the building was completed, many changes occurred, so that by the time the building was put into use, it was almost expired (John Warman, 1995). From this opinion, the construction of a new warehouse must be planned very carefully so that the warehouse will really be used effectively and efficiently. On the other hand, the warehouse is a facility that functions as a location for distributing weapons and ammunition from the warehouse to the user, in operational practice it tends to have an uncertainty about demand. This has prompted the emergence of policies to implement an inventory system so that demand can be carefully anticipated. With this policy regarding inventory, it is encouraging to provide warehouse facilities as a place to store inventory items. The warehouse is also a protection for goods and places with a reliable security system so that goods will get security guarantees from the dangers of theft, fire, flood, and other security problems. This is in line with Muchlisin Riadi's opinion "As a supply, it is very difficult to estimate the demand for weapons and ammunition accurately, so that it can serve users every time the warehousing operation can be used as an alternative place for inventory of goods which will function as storage and handling area stock" (Muchlisin Riadi, 2016).

Based on the Minister of Defense Regulation No. 12 of 2014 concerning the Principles of State Defense Material Development within the Ministry of Defense and the TNI, article 8 letter $\mathrm{d}$ regarding the classification of materials and article 9 letter a regarding the material for defense equipment. To support the effective and efficient distribution of weapons and ammunition, arsenal warehouses must separate or classify weapons and ammunition based on the function, size and level of danger of the weapons and ammunition stored, because the classification of weapons and ammunition will have implications for the position of development and the size of the warehouse to be built. The warehouse store will store weapons and ammunition consisting of various kinds such as missiles, torpedoes, large ammunition, small ammunition, weapons of various calibers and other equipment that requires warehouses with various specifications, to store and maintain these weapons and ammunition, warehouses required include:

- Missile Warehouse. This warehouse is used to store other inter-missile missiles: Exocet, Yakhon, C802, C705 and other missiles that are likely to be held from several countries. In addition to storing missiles, this warehouse is also equipped with a testbenk which is used as a place for maintenance, repair and testing before the missiles are distributed;

- Torpedo Warehouse. This warehouse is used to store torpedoes including: Black Shark, MK-46, A244S, SUT and other possible torpedoes from several countries. In addition to storing torpedoes, this warehouse is also equipped with a testbenk which is used as a place for maintenance, repair and testing before the torpedoes are distributed;

- Rocket Warehouse. This warehouse is used to store RM 90, Mistral AL-1, Seacat and other rockets that may be held from several countries. In addition to storing rockets, this warehouse is equipped with a testbenk which is also used as a place for maintenance, repair and testing before the rockets are distributed;

- Huge Ammo Warehouse. This warehouse is used to store large caliber ammunition including: $57 \mathrm{~mm}, 76 \mathrm{~mm}, 120 \mathrm{~mm}$ and other ammunition that may be held from several countries. In addition to storing large ammunition, this warehouse is also used 
as a place for maintenance, repair and testing before the large ammunition is distributed;

- Medium Ammo Warehouse. This warehouse is used to store $20 \mathrm{~mm}, 30 \mathrm{~mm}, 37 \mathrm{~mm}$ and $40 \mathrm{~mm}$ caliber ammunition. This warehouse in addition to storing ammunition is being used as well as a place for maintenance and repair before the large ammunition is distributed;

- Small Ammo Warehouse. This warehouse is used to store $5.56 \mathrm{~mm}, 9 \mathrm{~mm}$ and 12.7 $\mathrm{mm}$ caliber ammunition. In addition to storing small ammunition, this warehouse is also used as a place for maintenance and repairs before the large ammunition is distributed;

- Heavy Armory. This warehouse was used to store heavy weapons and cannons of $120 \mathrm{~mm}, 76 \mathrm{~mm}$ and $57 \mathrm{~mm}$ calibers. In addition to storing heavy weapons, this warehouse is also used as a place for maintenance and repair before the heavy weapons are distributed;

- Medium Armory. This warehouse is used to store medium weapons such as $20 \mathrm{~mm}$ caliber rifles, $30 \mathrm{~mm}, 35 \mathrm{~mm}$ and $40 \mathrm{~mm}$ caliber cannons. This warehouse in addition to storing weapons is being used as well as a place of maintenance and repair before the large ammunition is distributed;

- Light Armory. This warehouse is used to store small arms caliber $12.7 \mathrm{~mm}$ and below. In addition to storing light weapons, this warehouse is used as a place of maintenance and repair before the light weapons are distributed;

- Spare Parts Warehouse. This warehouse is used to store spare parts for light and medium heavy weapons; this warehouse is equipped with shelves and pallets adapted to the size of weapons and ammunition;

- Hand Grenade Warehouse. This warehouse is used to store hand grenades and launchers, this warehouse is equipped with shelves and pallets, the size is adjusted to the size of weapons and ammunition;

- Explosives Raw Material Warehouse. This warehouse is used to store explosive raw materials (TNT);

- $\quad T N T$ warehouse. This warehouse is used to store printed TNT;

- Detonator Warehouse. This warehouse is used to store detonators;

- Transit Warehouse. This warehouse is used to receive weapons and ammunition and check weapons and ammunition before entering the designated warehouse as intended.

The new construction or renovation of the warehouse to be built is adjusted to the technical specifications of the warehouse that can safely accommodate weapons and ammunition. Warehouses play a very important role in the supply chain. Therefore, the management system or governance must also be good and correct in order to continue to meet the needs or requests but at the minimum cost and efficient process. Therefore, there is a warehousing management system whose main function is to manage the available weapons and ammunition.

In order for warehouse management to run well, proper warehouse standard operating procedures (SOPs) are needed. Warehouse SOPs function to keep warehouse operations running as their main function is to support the achievement of company goals. Handling in the management of weapons and ammunition in the warehouse is carried out as well as possible and always maintains the quality of the goods so that they can be guaranteed safe when the goods reach their destination. Warehouse operations are made according to SOPs which include; Receipt of Goods, Inventory Data, Handling of weapons and ammunition and delivery of weapons and ammunition to the destination address. Currently the development of technology is growing. Almost all sectors use the internet as a result of the internet of things or IoT. One sector that participates in using internet technology is the warehousing sector. The use of internet technology aims to improve service performance for weapons and ammunition users. There are several warehousing technologies that can be implemented in warehouses. There are several tools and technologies that can be used to improve 
warehouse performance. Several technologies that can be implemented in warehouses include:

1. Warehousing Management System. One of the technologies that can be implemented in a warehouse is a warehousing management system, a comprehensive software system that functions to handle all important warehouse data into a single platform that can be easily accessed by selected warehouse personnel and given access from the warehouse supply chain. The use of warehouse management systems is not new anymore. However, now the warehouse management system is very modern with access to simultaneous data retrieval, increased visibility, which makes it possible to collect information more quickly and can predict results or user needs. This will make it easier for warehouse personnel when dealing with data to make reports quickly, and when used wisely, can make planning very efficient. With the increase in warehousing management technology, it is expected to increase the productivity of the arsenal. The way that can be used to improve the ability of warehouse crews in warehousing technology is to hold training, seminars and provide information and the latest changes in warehouse technology so that warehouse crews understand how to use the technology to the fullest.

2. Warehouse Computerization. Warehouse computerization is the use of computers as a means of data processing, where the problem to be given a solution by the computer must be translated into a number of definite steps of completion with a number of predetermined inputs and outputs. The benefits of computerized warehouses are to overcome problems in managing weapons and ammunition in warehouses, including: how to store and how long to store; how to search and how long to search; how to maintain; how to report and how long to report. Warehousing computerization also provides records of existing quantities, incoming quantities, shipped quantities and locations in the warehouse must be maintained using existing computer facilities. Computers can provide so many conveniences to improve warehouse management systems. If each area has a computer, of course, the warehouse crew can quickly upload all the details of the work to the warehouse management system. Having a connected computer with the right software can dramatically increase productivity in your arsenal.

3. Infrastructure Improvement. With the increasing technology used in warehousing, the arsenal also needs infrastructure improvements. Arsenal need to increase the electrical power or voltage to meet the new warehousing technology and the warehouse to get a supply of electrical energy according to the required capacity. In addition, that the location of the warehouse will get a backup of electrical energy if the main supply source is interrupted. Furthermore, arsenal also needs to increase the number of wifi routers in order to reach all parts of the warehouse, then arsenal also needs to increase internet speed. And what is needed next is a fire extinguisher that can inhibit and extinguish the fire so it doesn't spread far before the firefighters arrive. One of the fire fighting equipment that must be in the warehouse for example, a fire extinguisher, a hydrant system, an automatic fire sprinkler system and a fire engine.

4. Transportation Facilities. The means of transportation for distribution is an arrangement for the delivery of weapons and ammunition with a mode of transportation that aims to make the distribution process of weapons and ammunition more organized. That is, there is no delay in delivery and the quality of the goods is maintained until it reaches the user. To achieve that goal, the delivery process and the means of transportation must work in synergy. The service of weapons and ammunition to users requires adequate transportation facilities in the three arsenals, both weapons and ammunition transportation facilities for internal and external transportation facilities, so that there are no delays that will result in not carrying out operations carried out by users properly In peaceful conditions, the delay in distribution is not too fatal when compared to delays in war conditions. To be able to serve weapons and ammunition to users in the three arsenals to where the users are, the following means of transportation are needed: 
- Land Transportation. To support the smooth transfer of weapons and ammunition from the dock to the warehouse or vice versa and from warehouse to other warehouses in the arsenal environment, adequate means of transportation are needed in each arsenal. Transportation equipment for the needs of the three arsenal on land in order to support these activities consists of: Jetty Cranes, Mobile Cranes, Sky Walkers, Forklips, Trucks and other special vehicles.

- Sea Transportation. To support the distribution of weapons and ammunition to users who are on the outer islands and units that are carrying out operations that require weapons and ammunition and it is not possible to retrieve them for emergency reasons, it is necessary to support sea transportation in the form of $\mathrm{LCM}$ and $\mathrm{KRI} / \mathrm{KAL}$.

\section{CONCLUSION}

The current conflict in the South China Sea in addition to the tensions that occur due to overlapping claims between disputed countries, there are also negative developments, especially regarding relations between several regional countries and dragging many countries into it. Anticipating this tension into a conflict that threatens the sovereignty of the Indonesian state, the TNI must be strong and supported by adequate defense equipment.

To support operations carried out by the Indonesian Navy, the distribution of defense equipment, especially weapons and ammunition, greatly affects the success of the operations carried out. To realize this requires great effort, namely by dispersing the arsenal into three arsenals; Arsenal I in Tanjung Pinang, Arsenal II in Batuporon Madura, Arsenal III in Sorong. It is also necessary to optimize the arsenal of warehouses in the field of warehousing management systems, computerization of warehousing, improvement of infrastructure and improvement of transportation facilities, so that by increasing these two things, it will be able to increase the service of weapons and ammunition needs effectively and efficiently to users.

\section{REFERENCES}

1. A.T. Mahan. "The Influence of Sea Power Upon History 1660-1783." Scientia Militaria South African Journal of Military Studies 14 (February 28, 2012). https://doi.org/10.5787/14-1-536.

2. Al-Zu'bi, Zu'bi, Jay Heizer, and Barry Render. Operations Management, 2013.

3. Buszynski, Leszek. "The South China Sea: Oil, Maritime Claims, and U.S.-China Strategic Rivalry." The Washington Quarterly 35 (April 1, 2012): 139-56. https://doi.org/10.1080/0163660X.2012.666495.

4. Dr. H.A. Rusdiana, M.M. Manajemen Operasi. Bandung: CV Pustaka Setia, 2014.

5. E. ECCLES, HENRY. Logistics in the National Defense. First edition. Harrisburg, $\begin{array}{lll}\text { Pennsylvania: } & \text { THE } & \text { STACKPOLE }\end{array}$ https://www.marines.mil/Portals/1/Publications/FMFRP\%201214\%20\%20Logistics\%20in\%20the\%20National\%20Defense.pdf.

6. Edward Utama, Rony, and Nur Asni Gani. Operation management. First Printing. Ciputat, Tangsel, 2019.

7. Junef, Muhar. "Maritime Territory Disputes in the South China Sea." De Jure, n.d. http://dx.doi.org/10.30641/dejure.2018.V18.219-240.

8. Kep/555/VI/2018, TNI Commander Decree No. "Doktrin Tni Tri Dharma Eka Karma." Markas Besar TNI, June 2018.

9. Menkumham, Menhan. "Regulation of the Minister of Defense of the Republic of Indonesia Number 12 of 2014," 2014.

10. Myrian Dunn, Cavelty, and Victor Mauer. The Routladge Handbook of Scurity Studies. 270 Madison Avenue, New York, NY 1 0016: Taylor \& Francis e-Library, 2010.

11. Presiden, DPR. "UU RI NO 34 TH 2004 Tentang TNI," 2004. 
12. Riadi, Muchlisin. "Definition, Purpose and Benefits of Warehouse," n.d. https://www.kajianpustaka.com/2016/04/pengertian-tujuan-dan-manfaat-gudang.html.

13. Rosidin, Imam. "Why hasn't the TNI's defense equipment been modernized yet? This is Defense Minister Prabowo's answer." KOMPAS.Com, April 22, 2021. http://download.garuda.ristekdikti.go.id/article.php?article=1759033\&val=18739\&title=Sen gketa\%20laut\%20cina\%20selatan\%20dalam\%20perspektif\%20hukum\%20internasional.

14. Tandungan, Edmondus Sadesto. "South China Sea Dispute in International Law Perspective." PAULUS Law Journal Volume 1 No. 2 (March 2020). http://download.garuda.ristekdikti.go.id.

15. Taylor III, Bernard W., and Roberta S. Russell. Operations Management. 7Th Edition., 2011. http://www.wiley.com/go/permissions.

16. Warman, John. Warehousing Management. Jakarta: Pustaka Sinar Harapan, n.d.

17. Yayan, Patku. "Deterrence Effect," n.d. http://patriotgaruda.com/2015/05/20/deterrenceeffect/\#prettyPhoto. 